\title{
ERRATUM
}

\section{Imaginative Science Education}

\section{The Central Role of Imagination in Science Education}

\author{
Yannis Hadzigeorgiou
}

(C) Springer International Publishing Switzerland 2016

Y. Hadzigeorgiou, Imaginative Science Education,

DOI 10.1007/978-3-319-29526-8

\section{DOI 10.1007/978-3-319-29526-8_8}

In "Reference" section of the back matter, the author reference is correct but name of the author is to be updated. The name should be listed as Gilbert, A.

In Chapter 6 titled "'Wonder-Full' Science Education”, the in-text citations referring to "(Andrew, 2013)" on page 143 and 155 is also changed to "(Gilbert, 2013)". 